RESIDENT

\& FELLOW

SECTION

Section Editor

Mitchell S.V. Elkind,

MD, MS

K.-D. Choi, MD

H.-S. Lee, MD

J.-W. Bae, MD

H.Y. Choi, MD

H.-J. Kim, MD

Address correspondence and reprint requests to Dr. KwangDong Choi, Department of Neurology, College of Medicine, Pusan National University, 1-10 Ami-dong, Seo-gu, Pusan, 602-

739, Korea

kdchoi@medimail.co.kr
Supplemental data at www.neurology.org

\section{Teaching Video NeuroImages: Positional exophthalmos in orbital varices}

白

Figure

Gadolinium-enhanced axial MRI of the orbit in the supine position shows enhancing lesions in the left retrobulbar area (A), which become prominent in the prone position (B, arrowhead); accompanying exophthalmos of the left eye is also shown (B, arrow)
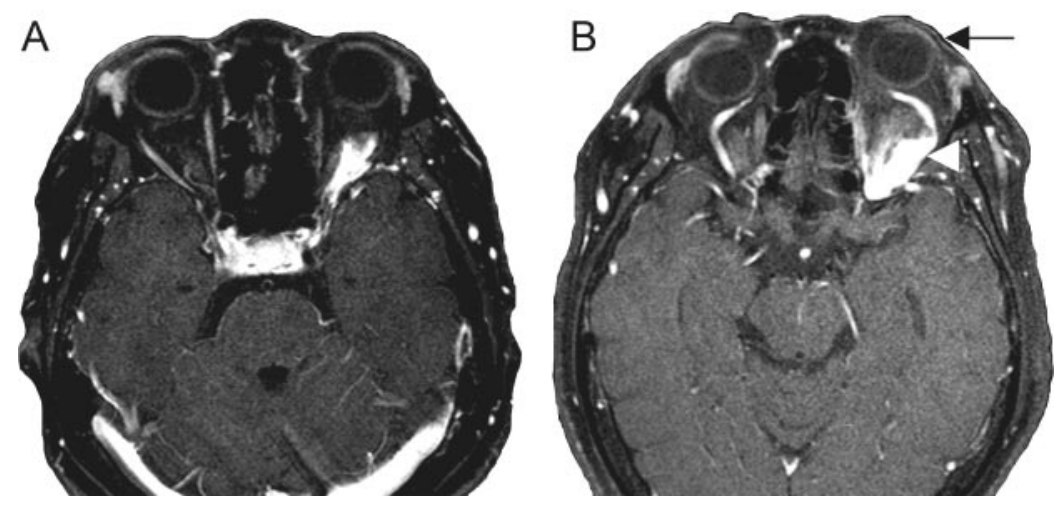

A 56-year-old woman presented with intermittent vertical diplopia and exophthalmos of the left eye, which become apparent when she was bending over. Examination disclosed mild limitation of supraduction and lid lag of the left eye. Bending over induced profound exophthalmos of the left eye (video) and aggravated vertical diplopia. The exophthalmos was confirmed by an exophthalmometer, which showed $16 \mathrm{~mm}$ right eye $/ 15 \mathrm{~mm}$ left eye in the supine position, and $16 \mathrm{~mm}$ right eye $/ 19 \mathrm{~mm}$ left eye in the prone position. Orbital MRI demonstrated enhanc- ing lesions in the left retrobulbar area in the supine position (figure, A), which became prominent in the prone position (figure, B).

Orbital varices are congenital vascular abnormalities with the presentation of intermittent, positional exophthalmos due to the constraint of the venous return by certain head postures. ${ }^{1}$

\section{REFERENCE}

1. Secil M, Soylev M, Ada E, Saatci AO. Orbital varices: imaging findings and the role of color Doppler sonography in the diagnosis. Comput Med Imaging Graph 2001;25:243-247.

From the Departments of Neurology (K.-D.C., H.-S.L., J.-W.B.), Ophthalmology (H.Y.C.), and Radiology (H.-J.K.), Pusan National University Hospital, Pusan National University School of Medicine and Medical Research Institute, Pusan, Korea.

Disclosure: The authors report no disclosures. 


\section{Neurology}

\section{Teaching Video NeuroImages: Positional exophthalmos in orbital varices}

K. -D. Choi, H. -S. Lee, J. -W. Bae, et al.

Neurology 2009;73; 8

DOI 10.1212/WNL.0b013e3181aae827

This information is current as of June 29, 2009

\section{Updated Information \&}

Services

Supplementary Material

References

Permissions \& Licensing

Reprints including high resolution figures, can be found at:

http://n.neurology.org/content/73/1/e8.full

Supplementary material can be found at:

http://n.neurology.org/content/suppl/2009/06/29/73.1.e8.DC1

This article cites 1 articles, 0 of which you can access for free at: http://n.neurology.org/content/73/1/e8.full\#ref-list-1

Information about reproducing this article in parts (figures,tables) or in its entirety can be found online at:

http://www.neurology.org/about/about_the_journal\#permissions

Information about ordering reprints can be found online:

http://n.neurology.org/subscribers/advertise

Neurology ${ }^{\circledR}$ is the official journal of the American Academy of Neurology. Published continuously since 1951, it is now a weekly with 48 issues per year. Copyright. All rights reserved. Print ISSN: 0028-3878. Online ISSN: 1526-632X.

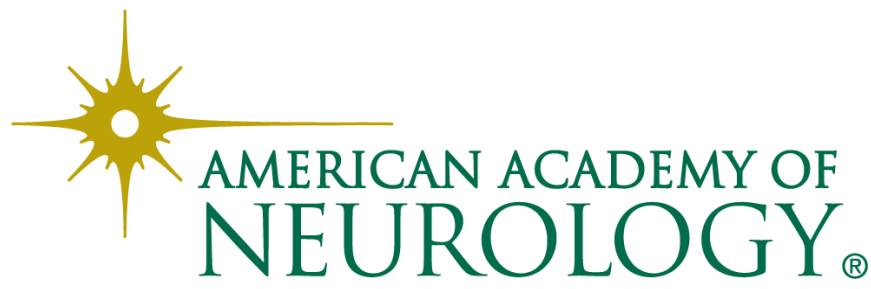

